\title{
School Principal's Strategies to Improve the Teaching Performance of Elementary School Teachers
}

\author{
Siti Maria Ulfa ${ }^{1 *}$, Edi Harapan ${ }^{2}$, Tahrun $^{2}$
}

\author{
${ }^{I}$ SDN 3 Makarti Jaya \\ ${ }^{2}$ Universitas PGRI Palembang \\ *Corresponding author. Email: sitimariaulfa116@gmail.com
}

\begin{abstract}
This study aims to identify the principal's strategy to improve the teaching performance of teachers at Public Elementary School SDN (SDN 3) Makarti Jaya. This type of research is descriptive qualitative research. Data collection tools used were documentation, interviews, observation and literature study. The data analysis technique was descriptive qualitative analysis technique which consisted of data collection, data reduction, data presentation, and conclusions. The results of the research stated that 1) the teaching performance of SDN 3 Makarti Jaya teachers was in good condition based on the indicators of the ability to manage learning; positive attitude towards their professional duties; skillful in making props; skillful in using various models and methods; skillful in interacting with students; and competence; 2) The principal's strategy in improving the performance of SDN 3 Makarti Jaya teachers was carried out by 1) establishing a program to improve the quality of learning through the school's vision and mission; 2) improving the quality of teaching among all teachers by encouraging teachers to improve their teaching competences and abilities; and 3) Creating a conducive school climate among others foster commitment in implementing learning activities that is by fostering the willingness of all school members to improve quality in a sustainable manner.
\end{abstract}

Keywords: Principal Strategy, Teaching Performance, Elementary School

\section{INTRODUCTION}

Improving the quality of learning is of course based on the reason for the low quality of education in Indonesia is low learning achievement [1]. It is strengthened by the statement of [2] which states that school output is high quality when student achievement is high. Thus, achievement is a proof of the success of educational institutions [3]

The results of observations made by researchers, it can be argued that the implementation of the 2013 curriculum at SDN 3 Makarti Jaya is still limited to the implementation of learning administration. Or in other words, the implementation of the 2013 curriculum at SDN 3 Makarti Jaya still has not absorbed the characteristics of the curriculum. This condition may occur due to the lack of competence of teachers who are strongly urged in the implementation of curriculumbased learning in 2013, the lack of enthusiasm for education, and the inability to carry out their professional duties.

Stated that the principal's strategy of maximizing the role of the teacher to improve the quality of learning through two strategies 1) maximizing the teacher's function as homeroom teacher; and 2) maximizing the teacher's function as a school extracurricular supervisor. The principal's strategy in maximizing the role of teachers at SDN 10 Betung was effective. It can be seen in the learning process in schools that do not experience problems even though the school is short of educators. Shows that the strategy adopted by the Principal can improve teacher performance in schools, the results of the study show: (1) discipline development; (2) set an example; (3) organizing seminars and training; (4) cooperate with other instances (5) bring in experts; (6) supervise; (7) optimizing educational facilities and infrastructure; (8) motivating teachers; (9) creating a harmonious working atmosphere; (10) involving teachers in every school activity; (11) freedom of opinion for the advancement of schools; (12) complete the needs of the teacher in charge; (13) awarding; and (14) pay attention to the welfare of teachers both mentally and materially. The research equation above, with the research to be examined is the same as making the principal's strategy and teacher performance the object of research.

The focus of the research carried out was "the principal's strategy in improving the teaching performance of teachers with sub-focus, namely 1) determining the quality improvement program of learning; 2) improving teacher teaching performance; 
and 3) creating a conducive school climate for teacher teaching performance". And the formulation of the problem can be determined, namely: "How is the principal's strategy to improve the teaching performance of SDN 3 Makarti Jaya teachers?"

This study aims to determine the principal's strategy to improve the teaching performance of SDN 3 Makarti Jaya teachers. And it is hoped that it can be useful to make a significant contribution to the development of science, especially the discipline of Education Management, providing information which can then be reviewed or re-examined regarding the leadership of school principals in improving teacher teaching performance.

\section{METHODS}

This research was conducted in SDN 3 Makarti Jaya. The research was carried out from July to November 2020. This research used descriptive qualitative methods. Data collection techniques in this study was by using observation, interview and documentation techniques. Thus, the researcher conducted interviews guided by the focus and sub-focus of research that had been compiled in an interview guide format. Interviews were conducted directly with several respondents, namely the principal and the teachers of SDN 3 Makarti Jaya to find out the principal strategy in improving the teaching performance of teachers as well as the teaching performance of the teachers themselves.

This study uses a qualitative descriptive approach to determine how the principal's strategy to improve the teaching performance of SDN 3 Makarti Jaya teachers. The qualitative descriptive approach in this study uses interview techniques, documentation, observation and literature review to strengthen the results of data collection in this stud.

\section{RESULTS AND DISCUSSION}

The profile of SDN 3 Makarti Jaya starts from the location of the area, the characteristics of educators and teaching staff, students, the standard of facilities and infrastructure, and the curriculum used in the school's core activities. SDN 3 Makarti Jaya is the only primary school in Purwosari village, so many children from other villages who do not have school go to Purwosari village. SDN 3 Makarti Jaya as one of the educational institutions within the Banyuasin Regency National Education Office, South Sumatra Province, which has an interest in continuing to develop the quality of education. SDN 3 Makarti Jaya has 302 students, with 15 groups with 1 class totaling +25 students with details of 160 male students and 142 female students spread over 6 class levels with 23 teachers.

Based on the results of data collection conducted by researchers using interviews conducted with resource persons consisting of the principal and teachers of SDN 3 Makarti Jaya then observation and documentation related to the principal's strategy in an effort to improve the teaching performance of SDN 3 Makarti Jaya teachers which includes the establishment of an improvement program, quality of learning; improving teacher teaching performance; and creating a school climate that is conducive to teacher teaching performance.

Igwe and Odike [8] emphasize that like other organizations, the success and failure of schools are very much closely related to the quality of leadership possessed by school principals. Therefore, schools as educational organizations must be led by school principals who can function their leadership roles properly. Tan [9] states that the principal as an educational leader has four functions, namely (1) managing the teaching-learning program, (2) designing the organisation to prioritize shared decision-making processes among numerous stakeholders, (3) creating an academic school vision and giving guidance, and (4) knowing and developing teachers. The role that the principal has is so complex. In addition to playing a role in managing schools to be effective and efficient, the principal in particular must also be able to improve teacher performance. Susanto [10] states that an increase in teacher performance in learning can be achieved if the principal as a leader is able to spur teachers to improve teacher performance seriously and with high dedication to the task at hand. Therefore, without adequate support from the principal for improving teacher performance, teachers will never carry out their duties, namely educating, training, guiding, and developing the potential of each student, to the maximum. Thus, to improve the quality of teacher performance, the role of the principal as an education leader needs to be further developed so that there is an increase in teacher performance.

Based on the research results it is known that the principal is very committed to the quality of learning. However, the principal's efforts to ensure the quality of learning need to be supported by increased teacher performance. The lack of depth in understanding the concept as a learning leader can be seen from the lack of efforts of the principal to implement programs to improve the ability of teachers to learn research-based learning models, the lack of opportunities that allow teacher collaboration in studying, analyzing, and finding joint solutions to a case of learning. The point is that the principal is only just committed to the quality of learning but has not run teacher performance improvement programs to improve the quality of learning.

The strategy of the principal of SDN 3 Makarti Jaya in improving teacher performance through improving the quality of teacher teaching is carried out by planning starting with identifying all possible problems with a needs analysis carried out by the principal of SDN 3 Makarti Jaya. Analysis is part of Total Quality Management. The needs analyst can place situations and conditions as input factors, which are then grouped according to their respective contributions. By conducting an initial needs analysis, the principal of 
SDN 3 Makarti Jaya can describe the situation that is being faced or that might be faced by the organization, especially the needs of SDN 3 Makarti Jaya teachers. This needs analysis can also help in the preparation of a mature plan to achieve goals.

\section{CONCLUSION}

From the results of research and discussion, it can be concluded that the principal's strategy in an effort to improve the performance of SDN 3 Makarti Jaya teachers is carried out based on some efforts. First, the principal established a program to improve the quality of learning through the vision and mission of the school, among others by implementing a program to improve the quality of learning into the vision and mission of the school. Then, the principal communicates the vision and mission of the school related to the quality standards of learning so that it can be realized in substantive policies in the field of learning. In order for these graduate standards to be achieved, the principal organizes learning activities according to the achievement targets. In addition, the principal also emphasized that the learning evaluation process carried out by the teacher be carried out objectively and continuously.

Next, the principal improved the quality of teaching among all teachers by encouraging teachers to improve their teaching competences and abilities. In order for the program of guidance and improvement of teaching skills to run optimally, the principal formed a team consisting of senior teachers as task executors to assist in the implementation of the program.

The last, the principal created a conducive school climate among others foster commitment in implementing learning activities; foster the willingness of all school members to improve quality in a sustainable manner; fostering the participation of school members in creating a safe and orderly environment; realizing good communication; implementing manpower management fosters high expectations of achievement, as well as giving awards for the successes achieved; and implement transparent management and strong accountability.

Based on the results, the principal should increase his competence so that the role of instructional leadership can have a maximum impact in efforts to improve teacher performance through improving the quality of learning. Teachers are expected to be more optimal in efforts to improve their performance through coaching programs held both by schools and outside schools such as workshops, training, seminars and training. Further researchers, should be able to research more specifically on improving teacher teaching performance.

\section{REFERENCES}

[1] Widodo, H. (2015). Portrait of Education in Indonesia and Its Concern in Facing the Asian Economic Community (MEA). Cendikia. Vol 13 No 2: 296-307.

[2] Oktriany, H. W. R., Triastuti, Y. S., Prajoko. (2015). Strategies for Improving Student Achievement Using Ishikawa Diagrams in SMA Negeri 1 Suruh. Proceedings of the National Seminar on Economics \& Business Education, Faculty of Teacher Training and Education, Sebelas Maret University, Surakarta.

[3] Winkel, W. S. (2013). Educational Psychology and Learning Evaluation. Jakarta: PT Gramedia.

[4] Sudjana, N. (2011). Coaching and Curriculum Development in Schools. Bandung: Sinar Baru.

[5] Wardani, D. K., \& Indriayu, M. (2015). Principal Learning Leadership to Improve Teacher Performance in Facing the Asean Economic Community. In the Proceedings of the National Seminar (Vol. 9).

[6] Prawirosentono, S. (2010). Productivity Management. Jakarta: PT. Bumi Aksara

[7] Yamin, M., \& Maisah. (2010). Teacher Performance Standards. Jakarta: Persada Press.

[8] Igwe, N. N. \& Odike, M. N. (2016). A Survey of Principals' Leadership Styles Associated with Teachers' Job Performance in Public and Missionary Schools in Enugu State Nigeria. British Journal of Education, Society and Behavioural Science, 17(2), 1-21

[9] Tan, C. Y. (2016). Examining school leadership effects on student achievement: the role of contextual challenges and constraints. Cambridge Journal of Education, 48(1), 21-45.

[10] Susanto, A. (2016). Konsep, Strategi, dan Implementasi Manajemen Peningkatan Kinerja Guru. Jakarta: Prenademedia Group. 